\title{
La decoración pictórica del cigarral del cardenal Quiroga
}

\author{
Cloe Cavero de Carondelet Fiscowich \\ Departamento de Historia y Teoría del Arte \\ Universidad Autónoma de Madrid \\ Real Fundación de Toledo (Proyecto de Investigación \\ Estudio del paisaje cultural de Toledo: Los cigarrales) \\ cloecavero@gmail.com
}

\section{RESUMEN}

El cigarral mandado construir a las afueras de Toledo por el que fuera uno de los personajes clave del reinado de Felipe II, el Inquisidor General y Arzobispo Primado Gaspar de Quiroga, a finales del siglo XVI, es uno de los monumentos renacentistas más desconocidos de nuestro patrimonio cultural. Hemos querido reconstruir la historia de este edificio analizando los restos arquitectónicos y pictóricos que perviven desde el análisis de la estrecha relación existente entre el cigarral y su dueño, relación que se hace patente en diferentes aspectos de su construcción y decoración.

Palabras clave: cigarral; Quiroga, Toledo; siglo XVI; pintura.

\section{The mural paintings of cardinal Quiroga's cigarral}

\begin{abstract}
The country house built by one of the key figures of Felipe II's kingdom, the General Inquisitor and Primate Archbishop Gaspar de Quiroga, at the outskirts of Toledo, is certainly one of the less known Renaissance monuments of our national heritage. We intend to re-construct this sixteenth century building's history by analysing the architectural remains and the fragments of mural paintings that have survived until present times, by the study of the close relation between the cigarral and his owner, a relation that shows up patently clear in several aspects of its construction and decoration.
\end{abstract}

Key words: cigarral; Quiroga; Toledo; sixteenth century; painting. 
A finales de 1584, el anciano cardenal Quiroga, apartado de la corte madrileña por motivos de índole política, decidió construir la que habría de ser su villa de retiro en la ciudad de la que era arzobispo, que sería descrita por el padre Mariana como "la soberbia quinta del cardenal Gaspar de Quiroga, el más suntuoso Cigarral de sus tiempos"'.

El prelado compró al toledano Hernán Suárez Franco una de las fincas situadas en uno de los cerros más allá del puente de San Martín, en las afueras de Toledo, por la importante suma de 6000 ducados $^{2}$. Probablemente, el motivo de esta particular elección radicaba en el deseo del cardenal por establecerse en la zona preferida por los intelectuales toledanos, quienes celebraban en esos pequeños cigarrales sus amenas tertulias literarias ${ }^{3}$. La casa elegida por el cardenal se levantaba en un lugar privilegiado, en lo alto de una de las muchas colinas de la zona, desde la cual se podía disfrutar de unas espléndidas vistas sobre la ciudad imperial.

El cardenal Quiroga decidió ampliar y ennoblecer este cigarral, que contaba únicamente con la casa, pozo, huertas y viñas acostumbrados ${ }^{4}$, erigiendo en su lugar una imponente construcción al estilo de las villas italianas. Para ello eligió al que había sido el maestro mayor de la catedral primada durante la mayor parte de su arzobispado, Nicolás de Vergara el $\mathrm{Mozo}^{5}$. Presumiblemente, dada su experiencia ${ }^{6}$, éste no sólo habría realizado las trazas del cigarral sino también el diseño de los cinco jardines decorados con fuentes y estanques ${ }^{7}$ que rodeaban el complejo.

Actualmente, los vestigios quinientistas de la casa principal están articulados mediante una loggia inferior, abierta a uno de los jardines, y un piano nobile, en el que se erige un imponente cimborrio octogonal, traducción exterior de la cúpula de media naranja que albergaba la capilla privada del cardenal (fig. 1). En esta cúpula encontramos uno de los dos ciclos pictóricos conservados, una escena de Pentecostés combinada con ocho pequeñas escenas del Antiguo Testamento. Separada del edificio principal, en una pequeña construcción secundaria de una sola planta, se conserva una estufa decorada con grutescos y escenas mitológicas. Si la estufa decorada con escenas mitológicas constituye el único ejemplo conservado en España de una costumbre arraigada entre los prelados italianos, tanto la temática elegida para decorar la

1 MARTÍN GAMERO, Antonio Los cigarrales de Toledo: recreación literaria sobre su historia, riqueza y población, Madrid, Severiano López Fando, 1857, p. 110.

2 AHPT, P. 1592, ff. 2080---2086; y MARTZ, Linda, A network of converso families in early modern Toledo: assimilating a minority, Ann Arbor: The University of Michigan Press, 2003.

3 MARTÍN GAMERO, A., Op. cit,, 1857, p. 84; RODRÍGUEZ, C., y MARTÍN, A., "Toledo en la época de Garcilaso", en BRABACHT, nº LVII, 1939, pp. 501-506.

4 HURTADO DE TOLEDO, Luis, Memorial de algunas cosas notables que tiene la Imperial Ciudad de Toledo, 1576 .

5 MARÍAS, Fernando, "El cigarral toledano del Cardenal Quiroga", en Goya, n 154, 1980, pp. 216-222. Se trata del primer estudio realizado sobre este cigarral, el cual toman como referencia el resto de textos publicados sobre el mismo.

6 MARÍAS, Fernando, Arquitectura del Renacimiento en Toledo (1541-1631), Madrid, IPIET, 1983-1986, tomo II, p.231.

7 AGP, Sección Administrativa, Toledo, Legajo 1298, Expediente 5. Agradezco la noticia de este documento al profesor Fernando Marías, bajo la dirección del cual llevé a cabo esta investigación. 


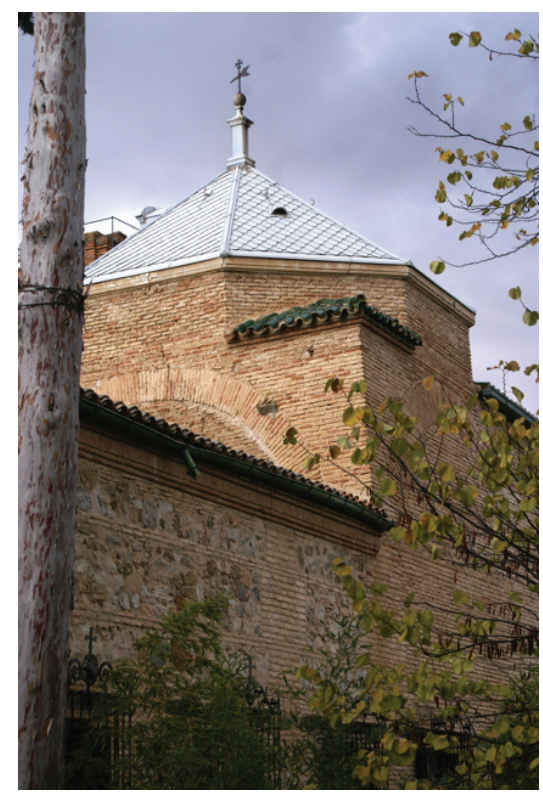

Fig. 1. Cigarral del cardenal Quiroga, Nicolás de Vergara el Mozo (ca. 1580-1588), Toledo.

cúpula de la capilla, la venida del Espíritu Santo sobre los apóstoles, como la estructura elegida para hacerlo la convierten en un unicum en la historia del arte.

La decoración pictórica se atribuye a Blas de Prado $^{8}$, pintor representante del estilo conocido con el nombre de "rafaelismo toledano". A pesar de no haber encontrado documentación al respecto, su autoría queda satisfactoriamente probada al ver el evidente parecido que guarda una pareja de figuras de la cúpula con dos personajes del dibujo autógrafo de La Ascensión de Cristo $^{10}$ que se conserva en la Biblioteca Nacional. La decoración se fecha hacia 1590, algunos años después de las labores de decoración de los jardines del cigarral ${ }^{11}$ y época en la que, por lo tanto, la arquitectura estaría acabada. De cualquier manera, el hecho de que bajo los actuales escudos del II marqués de Malpica pintados en las pechinas de la capilla y en los lunetos de la estufa, que representan las armas de Ribera Enríquez bajo una corona marquesal ${ }^{12}$, se

8 MARÍAS, Fernando, (1980), op. cit., pp. 216-222.

9 DE ANTONIO, Trinidad, "Los pintores españoles del siglo XVI y El Greco", en El Monasterio de El Escorial y la pintura. Actas del simposium, 1/5-IX-2001, R. C. U. Escorial-M Cristina, Servicio de Publicaciones, 2001, pp. 213-242.

10 PÉREZ SÁNCHEZ, Alfonso, El dibujo español de los siglos de Oro: salas de exposiciones del Palacio de Bibliotecas y Museos, Madrid, mayo 1980, Madrid, Ministerio de Cultura, 1980, p. 97, lám. nº 207.

11 AGP, Sección Administrativa, Toledo, Legajo 1298, Expediente 5; AHN, Inquisición, libro 361, f. 572rv, 578r; AMTo, Archivo Secreto: Alacena 2a , legajo 4, nº 6.

12 GARCÍA CARRAFFA, A, Diccionario heráldico y genealógico de apellidos españoles y americanos, Madrid, Antonio Marzo, 1920-1963, tomos 29 y 76; LÓPEZ DE HARO, A., Segunda parte del Nobiliario genealógico de los Reyes y títulos de España, dirigido a Felipe IV, Madrid, 1622, p. 74; y FATÁS, Guillermo, 
trasluzcan los restos de un escudo cardenalicio, hace que detrás de ambas decoraciones veamos los deseos de Gaspar de Quiroga.

Debido a la importancia del cardenal Gaspar de Quiroga, uno de los personajes capitales del reinado de Felipe II $^{13}$, que llegaría a ostentar los cargos de Inquisidor General y Arzobispo Primado, no debemos perder de vista el importante papel que el prelado debió tener en la ideación de la particular iconografía que hoy decora su villa de retiro, admirada y comentada por escritores como Francisco de Pisa o Tirso de Molina ${ }^{14}$.

\section{LA CAPILLA}

La decoración de la capilla se estructura mediante tres círculos concéntricos, combinando de una manera algo retardataria para la época la escena principal con ocho escenas accesorias. El círculo exterior acoge la escena de Pentecostés en forma de friso corrido a lo largo de todo el perímetro de la cúpula, y se completa con el coro angelical que debió acompañar a la paloma del Espíritu Santo, hoy escondida por el rosetón de una lámpara. En el círculo central vemos cuatro escenas veterotestamentarias en grisalla alternadas con otras cuatro en forma de monocromos broncíneos.

Si la Pentecostés es la representación de la Nueva Ley entregada al hombre en la forma de la sabiduría, las escenas que la acompañan no son sino ejemplos de hombres justos y sabios del Antiguo Testamento. Hay dos grisallas sobre episodios de la vida del rey Salomón, El juicio del rey Salomón y Adonías pidiendo clemencia a su hermano, intercaladas con otras dos sobre la vida del patriarca José ${ }^{15}$ que representan a José llamado a interpretar los sueños del Faraón y un momento de su infancia, José vendido por sus hermanos a los caravaneros ismaelitas. Los monocromos broncíneos, de menor tamaño y en peor estado de conservación, lo que dificulta notablemente su identificación, representan a su vez dos episodios de la vida de Moisés, Moisés y el milagro del agua en el desierto y Moisés en el Sinaí, y dos episodios de la vida de Abraham, El sacrificio de Isaac y El encinar de Mambré, una epifanía de la Trinidad. La representación de episodios de la vida de patriarcas de Israel es un recurso iconográfico relativamente común en el Renacimiento, utilizado también en la bóveda de la Estancia de Heliodoro en el Vaticano o en la Capilla de Luis de Lucena en Guadalajara.

Alonso de Villegas escribe en 1585 que "Nicolao de Lyra dice que la sabiduría de Salomón se ha de entender que fue grandísima a respeto de otros Reyes, porque dice,

y BORRÁS, G. M., Diccionario de términos de arte y elementos de arqueología, heráldica y numismática, Madrid, Alianza editorial, 1999.

13 PIZARRO, Henar, Un gran patrón en la corte de Felipe II: Don Gaspar de Quiroga, Madrid, Universidad Pontificia de Comillas, 2004.

14 DE PISA, F., Descripción de la imperial ciudad de Toledo y historia de sus antigüedades y grandeza... (Toledo 1605), Diputación Provincial, Toledo, 1974; DE MOLINA, T., Cigarrales de Toledo, Madrid, Espasa Calpe, 1968.

15 RÉAU, Louis, Iconografía del arte cristiano. Iconografía de la Biblia: Antiguo Testamento. Barcelona, Ediciones del Serbal, 1996, p. 188. 
que muchos otros fueron más sabios que él, y señala Adán que fue criado en plenitud de sabiduría: y Moisés con quien Dios hablaba, como suele un amigo hablar con otro. San Pablo, los Apóstoles, y particularmente el Evangelista San Juan que escribió el Apocalipsis, los cuales todos doce dice este doctor que fueron más iluminados, y supieron más que Salomón, y parece que puede confirmarse esto en cuanto a los Apóstoles, con lo que dice de ellos San Lucas, que fueron llenos de Espíritu Santo el día de Pentecostés" ${ }^{16}$. Villegas establece aquí la relación de Salomón, Moisés y los apóstoles con la sabiduría insuflada por Dios. Moisés recibió la sabiduría directamente de Dios Padre en la forma de la Antigua Ley, lo que le permitió guiar a su pueblo, de la misma manera que Salomón, al que el don de la sabiduría permitió, entre otras cosas, reinar con justicia. Por otro lado, José el patriarca no sólo fue ejemplo de virtud por resistirse a la mujer de Putifar, sino también de justicia y perdón, por sus actos en la corte del Faraón de Egipto y su comportamiento con sus hermanos.

Los temas elegidos por el cardenal Quiroga para decorar la cúpula de su capilla giran pues en torno a la sabiduría y la justicia, características necesarias para desarrollar satisfactoriamente sus labores como arzobispo e Inquisidor General, ideas incluidas en el lema que aparece en la filacteria de su escudo: amator iustitie protector Sapien$t_{i e^{17}}$. La temática de las virtudes del buen gobierno es también la elegida para decorar la fuente monumental de la galería inferior del cigarral ${ }^{18}$, en donde se representaron mediante animales características tales como la justicia, la castidad, la modestia, la prudencia o el amor por el prójimo.

En el contexto de la Contrarreforma, los valores subrayados en la Pentecostés, como son la institución de una clase eclesiástica superior que guíe la Iglesia, o la expansión misionera de la religión basada en la proclamación de la palabra de Dios, cobraron una especial importancia. Al analizar la escena perimetral de la cúpula vemos que ésta no se adecúa de manera satisfactoria a los textos sagrados, algo que resulta cuanto menos paradójico al tratarse de la capilla de un prelado contrarreformista e inquisitorial. La capilla del cardenal Quiroga muestra una particularidad importante: se trata de una Pentecostés populosa, es decir, aparecen en ella más personajes de los comúnmente aceptados. Además de los doce apóstoles, la Virgen María y las santas mujeres (fig. 2), reciben los dones del Espíritu Santo al menos treinta personajes más.

Pese a no estar especificado en el texto sagrado, la presencia de María en el suceso se acepta tradicionalmente porque se entiende que permaneció junto a los apóstoles en el cenáculo tras la oración del día anterior. Su inclusión es principalmente una elección simbólica y honorífica, como regina et mater Apostolarum ${ }^{19}$ y como símbolo de la Iglesia Católica, algo especialmente importante en los años tridentinos. No será hasta el Quattrocento italiano cuando encontremos a las santas mujeres, entre ellas María Magdalena, acompañando a la Virgen y a los apóstoles en el advenimien-

16 DE VILLEGAS, Alonso, Flos sanctorum, segunda parte y historia general en que se escriue la vida de la Virgen ... y la de los sanctos antiguos, que fueron antes de la venida de nuestro Saluador al mundo .. (1589), Toledo 1612, p. 193v.

17 DE VILLEGAS, Alonso, (1589), op. cit. .

18 AGP, Sección Administrativa, Toledo, Legajo 1298, Expediente 5.

19 RÉAU, Louis, Iconografía del arte cristiano. Iconografia de la Biblia: Nuevo Testamento. Barcelona, Ediciones del Serbal, 1996, p. 616. 


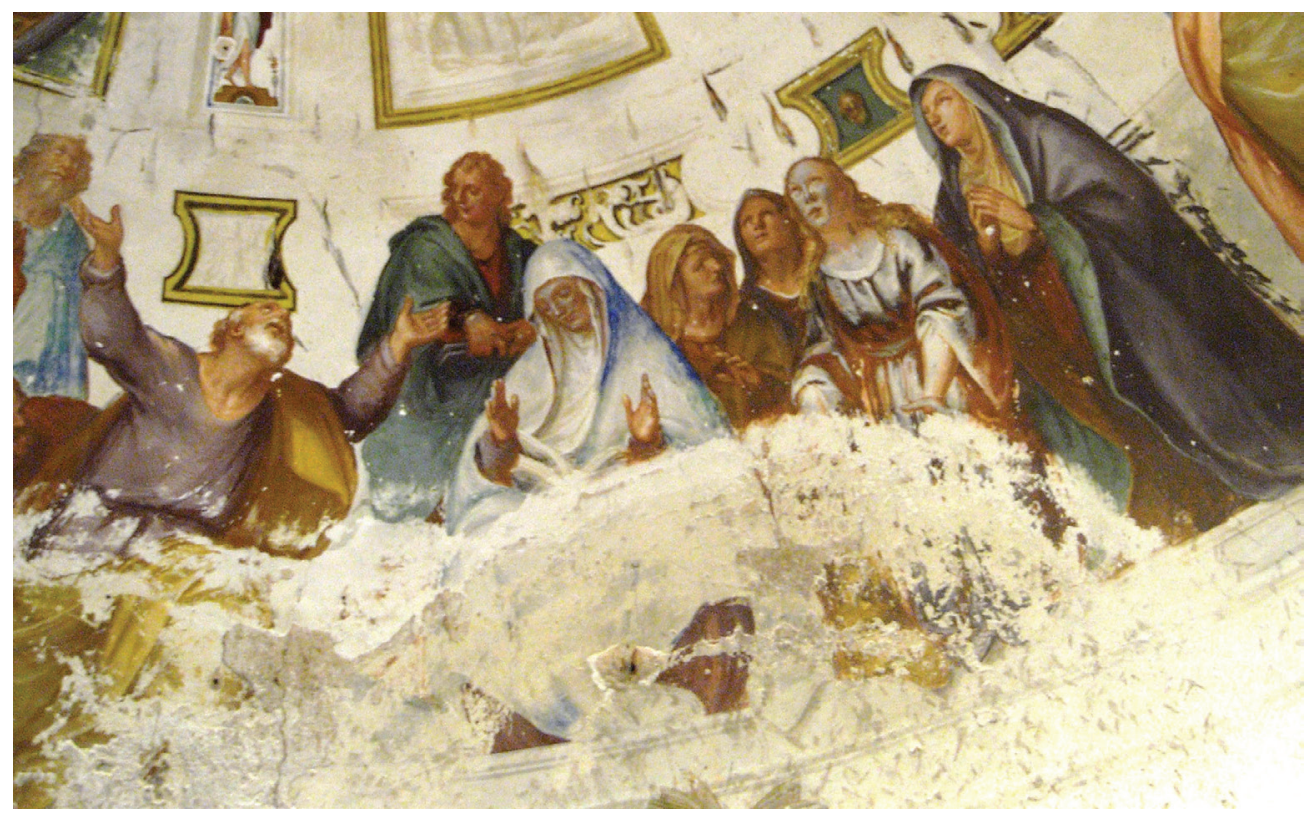

Fig. 2. Pentecostés [detalle: Virgen María y santas mujeres],Blas de Prado (ca. 1588), cigarral del cardenal Quiroga, Toledo.

to ${ }^{20}$. A partir de este momento será habitual encontrar esta nueva tipología, sin estar relacionado su uso con razones teológicas o devociones especiales.

Sin embargo, no encontramos entre las imágenes de la época presentes en España precedentes iconográficos que expliquen la presencia de los discípulos en la Pentecostés. La presencia en la escena de los discípulos no deriva pues de una tradición, sino quizá de la interpretación más amplia de los textos sagrados que tuvo lugar en Roma durante la segunda mitad del siglo XVI. En la que se admitió, de la misma manera en que se había hecho tradicionalmente en el caso de la Virgen, la presencia en el advenimiento de los discípulos que habían formado parte de la oración en el cenáculo el día anterior al suceso. En ese día:

“...la madre de Dios, se presume, que les habló y les dijo: Hijos míos, no os desconsoléis (...): hoy vendrá el que ha de enseñar la ley de amor en el mundo, el que es amor del Padre, y del Hijo. Pongámonos en oración, y con grande instancia pidámosle esta merced. Hiciéronlo así: pusiéronse a una parte los sagrados Apóstoles, a otra los santos Discípulos: la Magdalena con las demás santas mujeres que estaban allí, a otra: y la Madre de Dios en medio: asentados todos, que así lo nota el Evangelista, levan-

20 VALONE, Carolyn, “The Pentecost: Image and Experience in Late Sixteenth-Century Rome”, Sixteenth Century Journal, XXIV/4, 1993, p. 804. 
taron las manos y rostros al Cielo, comenzaron a derramar lágrimas, a dar gemidos y suspiros $(\ldots)^{\prime \prime 21}$.

El surgimiento de esta tendencia está ligado al pontificado de Gregorio XIII Buoncompagni ${ }^{22}$, quien nombró a Gaspar de Quiroga cardenal por el título de Santa Balbina en 1578. Gregorio XIII promovió una revalorización del episodio de la Pentecostés basada en la reforma litúrgica llevada a cabo por su predecesor Pío V y en los escritos de Gregorio Nacianceno. El pontífice vio en este episodio la conmemoración de la misión de predicación del apostolado y de la Iglesia, y por tanto la imagen que mejor se adecuaba a su afán de extender el maltrecho catolicismo romano a Grecia, al norte de Europa, al Nuevo Mundo e incluso a Asia. Uno de los primeros ejemplos de esta tendencia es la pintura encargada a Girolamo Muziano, en 1577, para decorar el techo de la Sala del Consistorio del Vaticano. Mediante la inclusión de los discípulos en la escena, Gregorio XIII enfatizaba su deseo por transmitir sus ideas expansionistas a los cardenales presentes en las reuniones consistoriales.

Pese a que el número exacto de discípulos presentes en el suceso quedaba definido en las escrituras, la interpretación de la misma quedaba abierta a dos posibles opciones. La opción con más seguimiento los establecía en ciento veinte, correspondientes simbólicamente a cada uno de los pueblos y lenguajes del mundo. Una segunda lectura del texto, hecha por el famoso predicador Fra Francesco Panigarola y basada en las escrituras de San Agustín, establecía el número de discípulos en setenta y dos, ya que defendía que el resto de lenguas sólo eran variaciones o mezclas de éstas. Sin embargo, y pese al supuesto rigor en el control de las imágenes existente en estos años, la inmensa mayoría de las Pentecostés populosas que se pintaron en Roma, no cumplieron estas exigencias teológicas, sino que optaron por representar una multitud indeterminada de discípulos acompañando a la Virgen y a los apóstoles.

A la vista de la relación que unió a Gregorio XIII con Quiroga en el último tercio del XVI, resulta natural pensar que nuestro cardenal estuviese al tanto de las reformas promovidas por el pontífice. Podríamos así explicar la elección de esta iconografía, rara por lo inusual en España, apoyándonos en la voluntad del cardenal arzobispo de plasmar sus intenciones apostólicas de la misma manera que lo había hecho Gregorio XIII. De esta manera, la capilla del cigarral pasaría de constituir un ejemplo aislado a ser parte de una tendencia litúrgica que moriría con el siglo XVI, debido al optimismo creciente de la Iglesia hacia la reunificación religiosa de Europa.

Tanto en la cúpula del cigarral toledano como en la mayoría de las pinturas del mismo tema realizadas en la época, los discípulos se confunden con los apóstoles. Esto es debido a que generalmente los apóstoles, una vez desprovistos de los atributos simbólicos con los que suelen aparecer en sus representaciones individuales, no cuentan con unas características fisonómicas determinadas. Si resulta imposible identificar individualmente a todos los apóstoles, sí es posible en cambio realizar una identificación grupal, colectiva, basándonos en su gestualidad. De esta manera, los doce personajes que se encuentran formando un grupo más o menos compacto

21 DE VILLEGAS, Alonso, (1589), op. cit., p. 56.

22 VALONE, Carolyn, (1993), op. cit. 


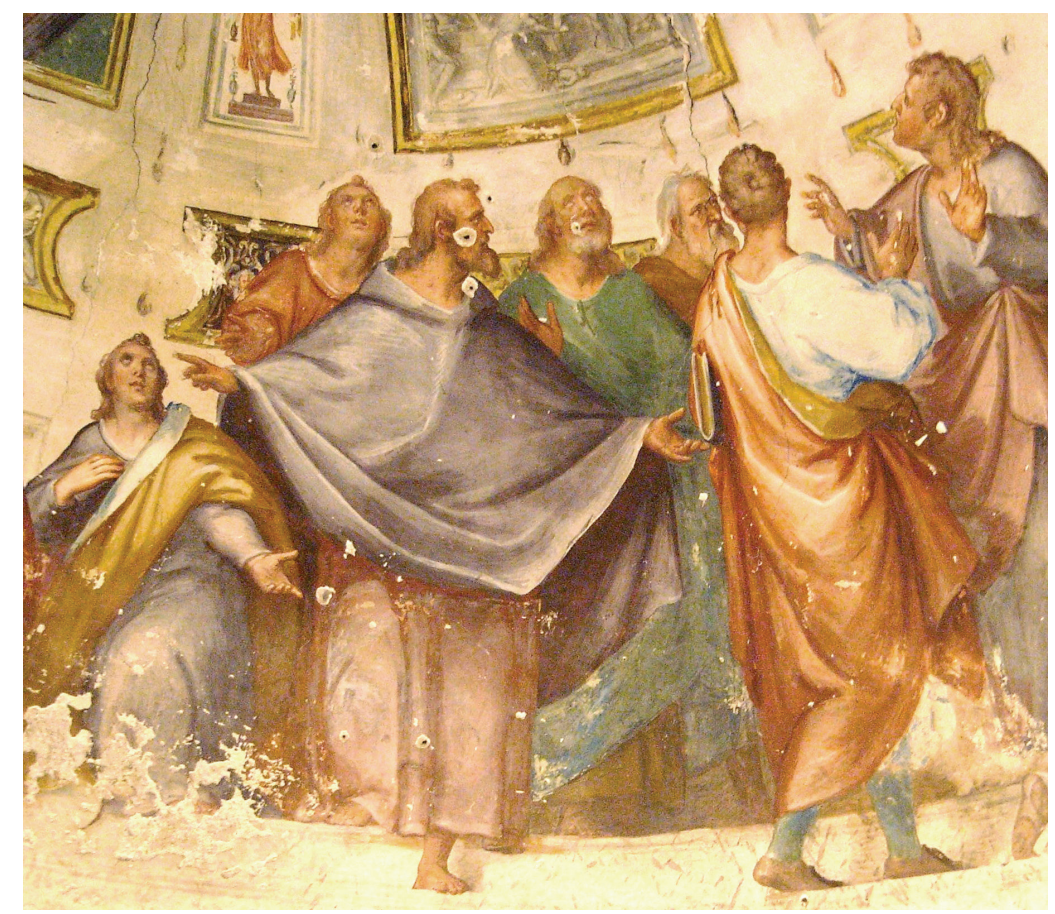

Fig. 3. Pentecostés [detalle: grupo de apóstoles], Blas de Prado (ca. 1588), cigarral del cardenal Quiroga,Toledo.

a la derecha de la Virgen, y en donde se incluyen los que podemos identificar como San Pedro, San Juan Evangelista y San Bartolomé, se corresponderían con los doce apóstoles, que reaccionarían a la llegada del Espíritu Santo de una manera calmada y contenida, propia de gente culta y cercana a Cristo (fig. 3). El resto de personajes, entre los que hay algunos niños, reaccionan de una manera excesiva al acontecimiento, y simbolizarían pues los ciento veinte discípulos que se encontraban en el cenáculo en el momento de la llegada del Espíritu Santo (fig. 4).

La desigual distribución de elementos anecdóticos ajenos a la narración bíblica a lo largo de toda la escalinata se convierte entonces en la herramienta elegida por el pintor para diferenciar a unos personajes de otros. Estos elementos, entre los que se encuentran cestos de paja rebosantes de paños, taburetes o un perro, han de ser valorados también como un recurso muy presente en España gracias a los lienzos de pintores venecianos como Tintoretto o Veronese. No deja de ser llamativo el hecho de que el cardenal Quiroga permitiese una licencia tal en su capilla, que había sido tachada de inapropiada en 1575, año en que a Navarrete el Mudo se le indica que no incluya en su pintura "gato ni perro ni otra figura que sea deshonesta" 23 .

23 DE ANTONIO, Trinidad, (2001), op.cit., p. 222. 


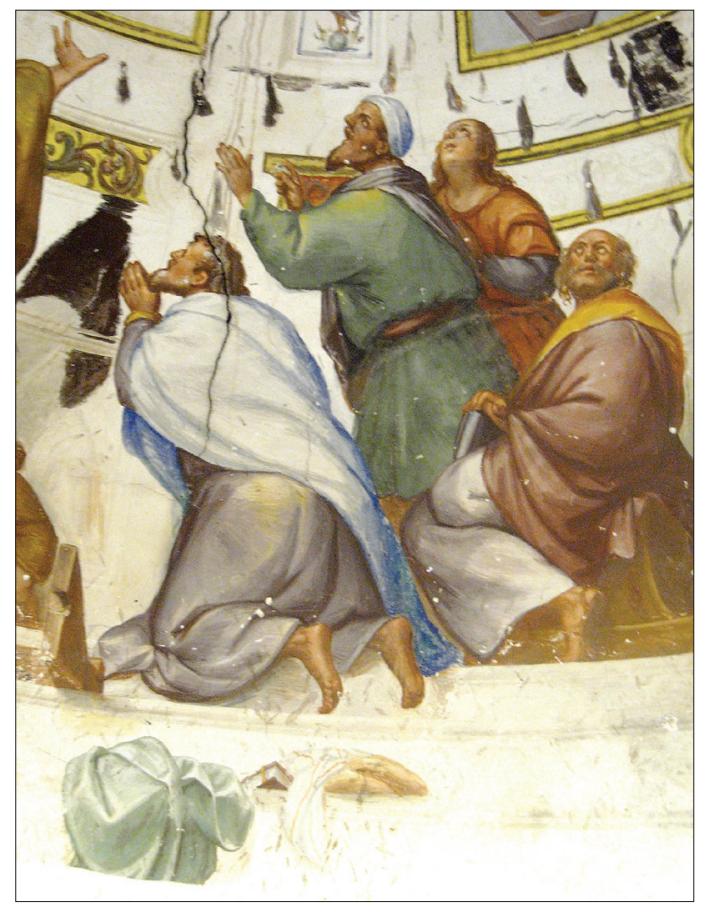

Fig. 4. Pentecostés [detalle: grupo de discípulos], Blas de Prado (ca. 1588), cigarral del cardenal Quiroga, Toledo.

Esta vaguedad en la solución de una cuestión que hoy nos parece tan importante nos lleva a pensar que en estos años la función de los apóstoles era grupal, que su propia naturaleza era la de conjunto más que de la suma de individuos. Como conjunto cumplían "una función ejemplarizante dirigida preferentemente al colectivo sacerdotal, como herederos de los enviados de Cristo, y en primer lugar a los prelados como cabezas de la iglesia" ${ }^{24}$, de acuerdo con los preceptos del Concilio de Trento. La representación de los apóstoles experimentó un impulso a comienzos del seiscientos en Toledo, época en la que una corriente reformada dedicada a recuperar los ideales del Cristianismo primitivo haría que eruditos como Salazar de Mendoza ligasen de manera directa en sus escritos los orígenes de la Iglesia toledana a los apóstoles, haciendo referencia a las estancias de algunos de ellos en la ciudad imperial ${ }^{25}$. Esta corriente se reflejaría en el campo de las imágenes en los Apostolados pintados en los primeros

24 MARÍAS, Fernando, "Los apóstoles del Greco entre ayer y hoy: de modelos ejemplares a "locos de Dios", en El Greco: Los Apóstoles, santos y "locos de Dios", catálogo de la exposición (Museo de Guadalajara-Antiguo Convento de la Merced de Ciudad Real, 16 septiembre 2010-28 enero 2011), Fundación El Greco 2014, 2010, pp. 15-51.

25 DE CARLOS, Ma Cruz., "Speculum pastorum”. Los apóstoles del Greco y la Iglesia toledana de comienzos del seiscientos", en El Greco: Los Apóstoles, santos y “locos de Dios", catálogo de la exposición 
decenios de siglo por El Greco, que podrían tener un precedente, si no formal sí al menos en intencionalidad, en la Pentecostés de la cúpula del cardenal Quiroga.

\section{LA ESTUFA}

Junto a uno de los jardines encontramos una pequeña construcción de cuatro estancias separada del edificio principal. Actualmente se conserva la decoración mural de una de ellas, el baño o estufa, lugar en el que fue redescubierta una bañera de granito a finales del siglo pasado. Mientras que la bóveda se encuentra decorada con motivos de grutescos sobre fondo blanco, sobre los muros vemos representado un ciclo de escenas mitológicas. Esta disposición se relaciona directamente con la decoración que ornaba las stufette, una decoración basada en las pinturas del palacio de Nerón y reinterpretada por Rafael a principios del siglo XVI. Quizá los ejemplos más conocidos sean las estufas del cardenal Bibienna en el Vaticano o del papa Clemente VII en el Castel Sant'Angelo. Estas dos estufas, decoradas una con motivos sobre fondo rojo y otra sobre fondo blanco respectivamente, son un ejemplo de cómo los artistas del siglo XVI procedieron a reinterpretar las fuentes iconográficas clásicas, creando así un nuevo tipo de decoración que inundó los palacios europeos.

En España tenemos los ejemplos de la estufa y logia de Carlos V en la Alhambra granadina, y de los desaparecidos aposentos construidos por Felipe II en el Alcázar madrileño en los años sesenta del siglo XVI, estos últimos probablemente decorados por el pintor español formado en Italia Gaspar Becerra ${ }^{26}$. El grutesco llegó a alcanzar en España un considerable nivel de popularidad, siendo utilizado no solamente como recurso marginal sino como protagonista de ciclos decorativos como los de los palacios del marqués de Santa Cruz y del duque del Infantado. Además, y pese a su discutido carácter profano y pagano, encontraremos ornamentación marginal a base de grutescos en las capillas privadas de los templos.

La decoración pictórica de la bóveda de la estufa se organiza a partir de un espacio octogonal central, que se irradia hacia la cornisa y hacia los cuatro lunetos que coronan la parte central de los muros. El desigual estado de conservación de la pintura de la bóveda frente a la pintura de las paredes, unido a indicios de repintes posteriores en toda la superficie y a una falta de unidad estilística con respecto al resto del ciclo, hace que su datación y atribución no sea firme.

El octógono central representa a los dioses Apolo, Mercurio, Minerva y Marte sentados en un cielo de oscuras nubes. La decoración del resto de la bóveda se organiza a partir de estructuras arquitectónicas y geométricas que ordenan las figuras en ocho ejes, correspondientes a los lados del octógono. Los cuatro ejes decorativos que evolucionan desde las esquinas comparten un mismo esquema compositivo. Sobre la esquina inferior de la bóveda está construida una finta arquitectura decorada

(Museo de Guadalajara-Antiguo Convento de la Merced de Ciudad Real, 16 septiembre 2010-28 enero 2011), Fundación El Greco 2014, 2010, pp. 53-83.

26 BARBEITO, J. M., El Alcázar de Madrid, Madrid, Colegio Oficial de Arquitectos de Madrid, 1992, pp. 48-49. 
con elementos broncíneos y hornacinas con estatuas. En estas hornacinas se apoyan parejas de putti sentados en diferentes actitudes, vertiendo el contenido de sus copas, calaveras y vasijas en conchas rosadas. La estructura arquitectónica está coronada por un sistema de guirnaldas y elementos decorativos manieristas, en cuyo centro hay representado un quadro riportato con distintas escenas, y junto al cual vemos una pareja de esfinges aladas pintadas en riguroso perfil. Sobre las guirnaldas encontramos una pequeña cornisa recta, en cuya parte superior hay una llama o un fuego divino al que se dirigen algunos humildes personajes en actitud de veneración y cargados con ofrendas. Por último, de la parte más cercana al octógono central pende un candelero, decorado profusamente con cintas y lazos.

Los cuatro ejes decorativos restantes, que ocupan una superficie mayor, están concebidos a partir de los lunetos del centro de los muros. En los pequeños abovedamientos de los lunetos están representados, siempre sobre fondo blanco, putti con cuernos de la abundancia sentados sobre nubecillas. De las tres esquinas resultantes del luneto y su bóveda se despliega una composición que recuerda en cierta manera, por su aparente fragilidad y por los adornos vegetales y florales, a las pérgolas propias de cenadores o jardines. A ambos lados vemos representadas cariátides sobre finas columnas, aves llenas de color, tritones y figuras fantásticas sosteniendo palmas y cintas, espirales y ramas. Coronan las estructuras arquitectónicas centrales, decoradas con relieves broncíneos simulados, cuatro figuras que sostienen largas ramas.

La condición apartada y sencilla de esta construcción, confiere a toda la decoración que la orna un carácter más bucólico e íntimo, alejado de las facetas más refinadas y complicadas de la vida cortesana y ciudadana. Entre las inevitables cariátides y figuras híbridas propias del grutesco están representadas con enorme delicadeza y detallismo aves comunes, elementos vegetales y pequeñas escenas de carácter costumbrista en donde campesinos ataviados con sencillez portan humildes ofrendas tales como carneros o sencillos ramos de flores. Los pájaros no son sino especies comunes como la abubilla, el verderón, el rabilargo o el abejaruco. La bóveda de la estufa se convierte así en un exponente de las ramas más naturalistas del género del grutesco, tendencia decorativa adoptada por Felipe II en sus casas de campo ${ }^{27}$ y seguida por los nobles y por los personajes poderosos deseosos de emular los regios gustos del monarca.

La decoración de la bóveda se completa con una pequeña procesión que discurre a lo largo de toda la cornisa. Sobre un pequeño friso decorado con roleos vegetales, niños y enanos desfilan en las actitudes más bizarras. Aparecen en ocasiones disfrazados, corriendo y danzando, jugando o tocando instrumentos musicales, andando sobre zancos o haciendo piruetas, aportando con sus movimientos algo de dinamismo al estatismo predominante en la bóveda. Pese a no ser una iconografía muy común, sí hemos encontrado imágenes de procesiones de carácter fantástico protagonizadas por niños en algunos de los bajorrelieves de las Logias de Rafael.

27 GARCÍA-FRÍAS CHECA, C, "Gaspar Becerra y la pintura clasicista entre Roma y España”, en Roma y España, un crisol de la cultura europea en la Edad Moderna (actas del Congreso Internacional de la Academia de España en Roma del 8 al 12 de mayo de 2007), Madrid, Sociedad Estatal para la Acción Cultural Exterior, 2007, vol. I, p. 383. 
En el interior de cada uno de los tres lunetos en los que se conserva decoración mural vemos la representación de un ángel sentado en un cielo de nubes y sosteniendo un escudo ovalado (fig. 5). Estas figuras angélicas son características de la maniera de Blas de Prado, con ampulosos mantos y un gran volumen. Hemos querido ver un precedente lejano, por el uso del cielo como fondo, en los lunetos inspirados en las Metamorfosis de Ovidio pintados por Sebastiano del Piombo en la sala de Galatea de Villa Farnesina.

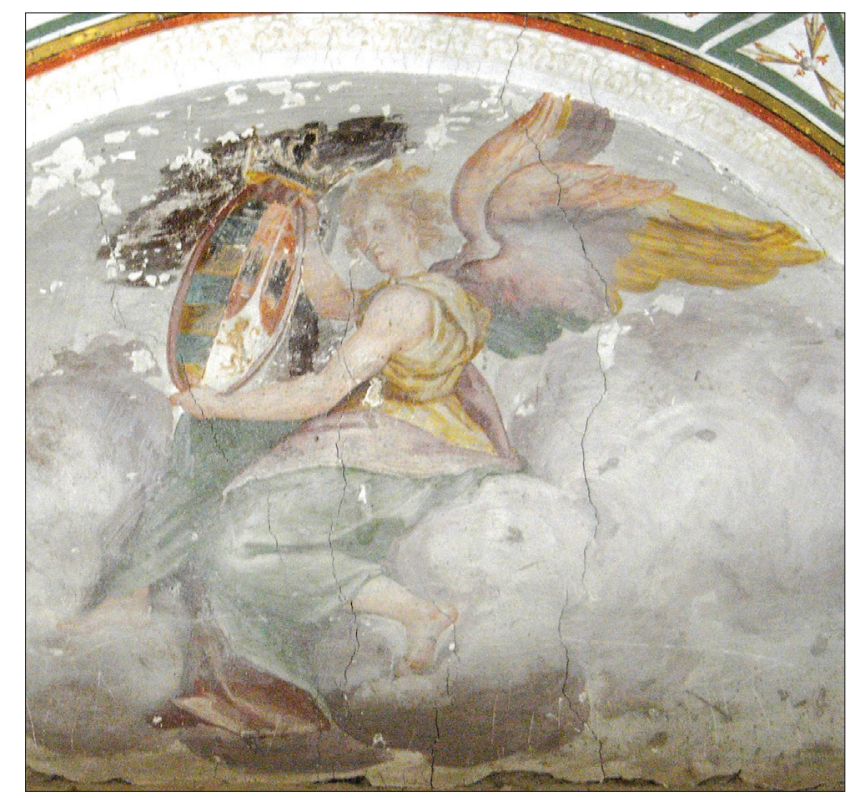

Fig. 5. Ángel portando las armas de la familia Ribera

Enríquez, Blas de Prado (ca. 1588), cigarral del cardenal Quiroga, Toledo.

La decoración de las paredes es la más castigada por el paso del tiempo, ya que al progresivo deterioro de la pintura se suma una invasiva intervención en las únicas tres paredes que conservan la pintura, que desvirtúa su contemplación. Las escenas están estructuradas a partir de los vanos que se abren en los muros, tanto de las ventanas como de las puertas que comunican las estancias entre sí. Los dos muros interiores comparten la misma estructura compositiva, una única escena central enmarcada por anchas bandas de roleos y elementos decorativos manieristas, y acompañada por dos figuras femeninas sedentes sobre los vanos. Podemos reconocer en estas las escenas de Diana y Acteón y Diana y Endimión respectivamente. En la pared que da al jardín hay pintadas dos escenas, una a cada lado del vano central, sobre el cual se ha pintado una estructura arquitectónica. La temática de la escena izquierda parece representar el episodio del Rapto de Europa, huyendo a lomos de un toro sobre las olas del mar, mientras que en la escena derecha reconocemos la figura de Narciso, 
consumiéndose de amor por la contemplación de su propia imagen en el agua. Estas escenas mantienen asimismo una estrecha relación estilística con la obra conservada de Blas de Prado, tanto en la concepción de las figuras como en la relativa sencillez de las composiciones.

Durante todo el siglo XVI fue común la utilización de episodios extraídos de la mitología clásica para adornar estancias dedicadas al baño. Como apunta acertadamente Fernando Checa, los episodios no se elegían únicamente por su relación más o menos cercana con los temas de agua y naturaleza, sino también por su faceta de erotismo, encontrado en ello un ejercicio de evocación de la Antigüedad ${ }^{28}$. En la Domus Áurea y en las stufette del cardenal Bibbiena y de Clemente VII encontramos escenas mitológicas insertas en la decoración de grutesco, representado divinidades en contacto con la naturaleza y el agua, como son Venus, Diana y las ninfas.

En España los ejemplos más cercanos los encontramos de nuevo en encargos regios. Una de las primeras muestras de este nuevo gusto por el erotismo es el ciclo de los Amores de Júpiter pintado por Correggio y regalado al emperador Carlos V por Federico de Gonzaga en 1530. Felipe II encargaría decorar diferentes estancias del Alcázar madrileño y del palacio de El Pardo con episodios provenientes de la mitología clásica, además de encargar a Tiziano las llamadas Poesías. Mientras que de los ciclos decorativos al fresco que debieron adornar estos dos palacios únicamente subsisten los frescos de Dánae pintados por Gaspar Becerra en 1562 para el palacio de El Pardo, sí conservamos en cambio todas las pinturas de Tiziano. Felipe II encargó al pintor veneciano un ciclo inspirado en Las Metamorfosis de Ovidio, que incluía las escenas de Diana y Acteón, Diana y Calixto, Dánae, Venus y Adonis, el Rapto de Europa, la Muerte de Acteón y Perseo y Andrómeda. Estos lienzos unían a los escenarios naturalistas un claro protagonismo del desnudo femenino, convirtiendo así a Diana, Venus y Andrómeda en exponentes del erotismo buscado por el monarca. Este ciclo, espléndido en factura y color, tiene puntos en común con las escenas que decoran las paredes de la estufa del cigarral. Tanto en Diana y Acteón como en el Rapto de Europa vemos el uso de una composición bastante parecida a las inventadas por Tiziano.

Sin embargo, pese a la espléndida arquitectura y decoración, el anciano cardenal no llegaría a disfrutar de su villa toledana, ya que poco tiempo después de su construcción fue llamado a Madrid, donde moriría sin tener oportunidad de volver a Toledo. El cardenal y arzobispo primado Sandoval y Rojas sería el primero en continuar la tendencia instaurada por el cardenal Quiroga, construyendo un cigarral con jardines, estanques, fuentes y estatuas clásicas a orillas del Tajo ${ }^{29}$.

28 CHECA, Fernando, Felipe II, mecenas de las Artes, Madrid, Nerea, 1993, pp.134-142.

29 MARÍAS, Fernando, (1983-1986), op. cit., tomo III, pp. 142.144. 